\title{
Reduction of the Backing Gas Sequence as a Facile Method to Improve Corrosion Resistance in Duplex Stainless Steel (DSS) Weldment
}

\author{
Basuki Tri Laksono ${ }^{1}$, Hendri Budi Kurniyanto ${ }^{2 *}$, Purwa Sadewa ${ }^{2}$ and \\ Riza Wirawan ${ }^{1}$
}

${ }^{1}$ Faculty of Mechanical and Aerospace Engineering, Institut Teknologi Bandung, Jalan Ganesa No. 10 Bandung 40132, Indonesia

${ }^{2}$ Welding Engineering Department, Shipbuilding Institute of Polytechnic Surabaya, Jalan Teknik Kimia ITS Sukolilo Surabaya 60111, Indonesia

\begin{abstract}
Duplex stainless steel (DSS) is an important material used for corrosion resistance in various harsh environment plants such as petrochemical, offshore subsea component, and other chemical industries. An approximately equal amount of austenite and ferrite $(\mathrm{A} / \mathrm{F})$ ratio grants good mechanical properties and rust protection on. The detrimental intermetallic phase frequently occurs due to an unbalanced A/F ratio caused by the welding's thermal cycle. Backing gas is commonly applicable in the field combined Gas Tungsten Arc Welding (GTAW) process. However, the use of backing gas to complete a single weld from root to cap joint required huge additional costs for consumables. Maintaining the thermal cycle in the welding parameter and GTAW process with ER2209 filler metal for DSS below $10 \mathrm{~mm}$ thick can reduce the backing gas sequence. The research aims to efficiently substitute full backing gas consumption, which meets a desirable quality in terms of corrosion resistance. The effect of backing gas reduction was studied. All specimens were tested by visua Vickers microhardness,

ARTICLE INFO

Article history:

Received: 07 May 2021

Accepted: 22 August 2021

Published: 28 October 2021

DOI: https://doi.org/10.47836/pjst.29.4.41

$\overline{\text { E-mail addresses: }}$

basukitrilaksono@gmail.com (Basuki Tri Laksono)

hendribudi@ppns.ac.id (Hendri Budi Kurniyanto)

purwasdw@gmail.com (Purwa Sadewa)

riza.wirawan@itb.ac.id (Riza Wirawan)

* Corresponding author

metallography, ferrite content measurement, and electrochemical corrosion test. The visual test shows no defects beyond the range of the ASME IX acceptance and criteria. The evaluation comes from the ferrite scope and electrochemical corrosion test. The backing gas on the root weld shows a balance $\mathrm{A} / \mathrm{F}$ ratio of around $38 \%$ ferrite content accepted in various standards. The
\end{abstract}


backing gas sequence on the root until filler-pass obtained $0.04 \mathrm{~mm} / \mathrm{year}$, which is the desirable corrosion resistance and met the requirement of ASTM A932.

Keywords: Backing gas, corrosion resistance, detrimental intermetallic phase, duplex stainless steel, GTAW

\section{INTRODUCTION}

Due to their lightweight and long life-cycle, Duplex Stainless Steel is commonly used in oil and gas plants, construction, petrochemical, and others chemical industries. The local microstructure of DSS is heavily influenced by the fabrication process, especially the welding process (Bhattacharya \& Singh, 2007; Chen \& Yang, 2002). During multipass welding, the microstructure of DSS can transform to the detrimental phase, such as chromium nitride precipitation and secondary austenite formation, leading to significant unbalanced the austenite-to-ferrite (A/F) ratios (Badji et al., 2008; Chan \& Tjong, 2014; Liou et al., 2002; Varbai et al., 2019; Zhang et al., 2016). As a result, the DSS acquires a dual microstructure consisting of an approximately equal volume fraction of a-ferrite and g-austenite phases. However, the unequal $\mathrm{A} / \mathrm{F}$ ratio is frequently encountered due to heat input and reheat cycles, decreasing ductility, toughness, and corrosion resistance (Varbai et al., 2019; Verma \& Taiwade, 2017; Wang et al., 2011). Moreover, the DSS may become more prone to stress corrosion cracking in the presence of high temperature, tensile stress, and an aggressive environment (Bhattacharya \& Singh, 2007; Verma \& Taiwade, 2017).

The $\mathrm{A} / \mathrm{F}$ ratio is an important factor in the welding of DSS. Several studies have been performed to mitigate the excessive contraction of austenite content in the weld metal. For example, Verma et al. (2017) reported that higher austenite composition was obtained during quenching if the welding filler metal had $2 \%$ to $4 \%$ more Ni than the base metal. However, researchers tried to replace the filler metal of Ni-based alloy over ER 2209 due to the fluctuation of Ni-based alloy, which can be ten times more expensive (Lippold et al., 1988; Nana \& Cortie, 1993). The effect of mixing 2\% nitrogen added $98 \%$ argon as backing gas for greater than $10 \mathrm{~mm}$ thickness, improving the corrosion resistance (Sales et al., 2016). Furthermore, several authors reported utilising nitrogen in the shielding and backing gas, leading to an increase of the austenite formation and lower chromium nitrides in the weld metal microstructure (Baghdadchi et al., 2020; Betini et al., 2019; Gozarganji et al., 2021; Liu et al., 2020; Matsunaga et al., 2013; Muthupandi et al., 2005). In contrast, the unbalance $\mathrm{A} / \mathrm{F}$ transformation still occurred even with mixing a small percentage of nitrogen in argon for shielding gas or backing gas because the solubility and diffusion kinetics of atomic nitrogen in the solid-state is not in the liquid phase. Thus, the solution to obtain the balance $\mathrm{A} / \mathrm{F}$ phase transformation governed by thermal exposures can control the welding parameters such as the subsequent cooling rate, proper filler metal selection, and maintaining heat input (Varbai et al., 2019). The correct thermal setting of duplex stainless 
steel eliminates these detrimental phases. Rapid cooling during the thermal exposures in the temperature range 320 to $955^{\circ} \mathrm{C}$ provides the maximum resistance to the formation of detrimental phases by subsequent thermal exposures (Geng et al., 2015; Ramkumar et al., 2015).

Although many studies on the detrimental phases such as chromium nitride and austenite precipitation in DSS while welding process has been reported (Baghdadchi et al., 2020; Betini et al., 2019; Gozarganji et al., 2021; Karlsson et al., 1995; Lippold \& Kotecki, 2005; Liu et al., 2020; Matsunaga et al., 2013; Muthupandi et al., 2005; Ramirez et al., 2003), not much work has been done to simplify the DSS's welding method by reducing backing gas consumption. In this research, the authors simplified its method by varying sequences of backing gas. Generally, the backing gas is served from the start to the end of the welding process, requires much shielding gas consumption (Sales et al., 2016). GTAW is one of the most popular technologies for welding DSS because it produces soundness welds that meet service requirements (Chern et al., 2011; Zhang et al., 2016). Soundness weld means the degree of freedom from defects in the weld, which is found by visual inspection of any exposed welding surface. Geng et al. (2015) found E/ER 2209 with different processes for joining similar and dissimilar DSSs shows better corrosion resistance and mechanical properties. Therefore, the research aimed to use the combination of GTAW and the E/ER 2209 for DSS below $10 \mathrm{~mm}$ thick. Reducing the backing gas sequence method can optimally and efficiently substitute full backing gas consumption, costing a desirable quality corrosion resistance standard.

In the present work, the influence of each reduction of the backing gas sequence was further investigated. Special attention was given to the influence of the R-F joint and the $\mathrm{R}$ joint on the corrosion resistance and ferrite content. The ferrite content was measured by ferrite-scope, while a light microscope analysed the microstructure of its varying joint. Also, the corrosion rate of the varying joint was evaluated by utilising the electrochemical test.

\section{MATERIAL AND METHODS}

The base metal studied in this research was the DSS type 2205; according to ASME section II part C and section IX QW/QB-422, the material can be categorised as SA 240 type 2205 UNS No. S31803, P-No =10H, Group No $=1$.

Table 1

Chemical composition of the DSS type 2205 and ER2209

\begin{tabular}{cccccccccc}
\hline \multirow{2}{*}{ Type } & \multicolumn{10}{c}{ wt \% } \\
\cline { 2 - 10 } & $\mathrm{C}$ & $\mathrm{Mn}$ & $\mathrm{P}$ & $\mathrm{S}$ & $\mathrm{Si}$ & $\mathrm{Cr}$ & $\mathrm{Ni}$ & $\mathrm{Mo}$ & $\mathbf{N}$ \\
\hline $\mathbf{2 2 0 5}$ & 0.02 & 0.95 & 0.02 & 0.01 & 0.95 & 22.00 & 5.00 & 3.00 & $\mathbf{0 . 1 8}$ \\
ER2209 & 0.013 & 1.54 & 0.018 & 0.007 & 0.49 & 22.92 & 8.61 & 3.18 & $\mathbf{0 . 1 7}$ \\
\hline
\end{tabular}


The base metal was machined to $300 \mathrm{~mm} \times 300 \mathrm{~mm} \times 6 \mathrm{~mm}$ to form a single V-groove of $60^{\circ}$. The joints were carried out by filler metal of $\varnothing 2.4 \mathrm{~mm}$ ER2209. The chemical composition of DSS type 2205 plates and ER2209 were analyzed as given in Table 1.

These specimens were welded using GTAW. The welding was conducted manually on the $1 \mathrm{G}$ (flat) welding position with direct current straight polarity and maintained interpass temperature at approximately $150^{\circ} \mathrm{C}$. The Ultra-High Purity (UHP) of $99.99 \%$ Argon gas served as a shielding gas and backing gas. The backing gas flow path installation of was commenced by sticking aluminium foil and tacked welds, as shown in Figure 1. Once the utilisation sequence of backing gas eliminates each welding layer, it will affect the cooling rate during welding. For example, the R-C joint also accelerates the interpass temperature because backing gas is served to protect the weld pool during welding from the other atom

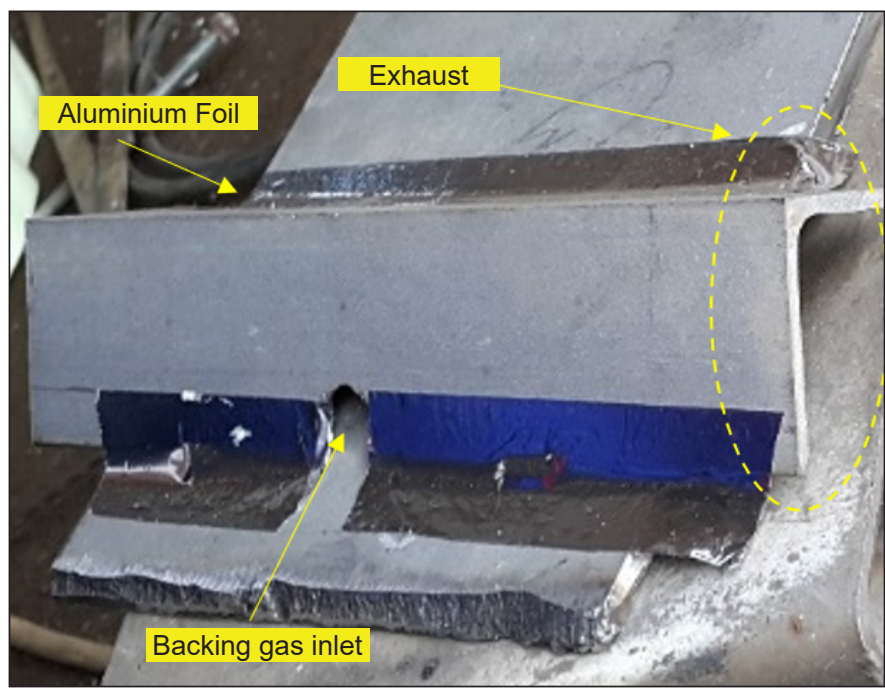

Figure 1. Configuration of backing gas flow path

Table 2

Welding parameter

\begin{tabular}{ccccccccc}
\hline \multirow{2}{*}{ ID } & Weld & Weld & Current & Voltage & Travel speed & Heat input & \multicolumn{2}{c}{ Flow rate (1/min) } \\
\cline { 7 - 8 } & pass & run & $(\mathrm{A})$ & $(\mathrm{V})$ & $(\mathrm{mm} / \mathrm{min})$ & $(\mathrm{kJ} / \mathrm{mm})$ & Backing gas & Shielding gas \\
\hline \multirow{2}{*}{ R-C } & 1 & Root & $95-110$ & $9-10$ & $65-75$ & $0.9-1.0$ & $10-15$ & $10-15$ \\
& 2 & Fill & $110-120$ & $11-12$ & $75-90$ & $0.9-1.0$ & $10-15$ & $10-15$ \\
& 3 & Cap & $120-130$ & $11-12$ & $65-75$ & $1.0-1.3$ & $10-15$ & $10-15$ \\
\hline \multirow{3}{*}{ R-F } & 1 & Root & $95-110$ & $9-10$ & $65-75$ & $0.9-1.0$ & $10-15$ & $10-15$ \\
& 2 & Fill & $110-120$ & $11-12$ & $75-90$ & $0.9-1.0$ & $10-15$ & $10-15$ \\
& 3 & Cap & $120-130$ & $11-12$ & $65-75$ & $1.0-1.3$ & - & $10-15$ \\
\hline \multirow{2}{*}{$\mathrm{R}$} & 1 & Root & $95-110$ & $9-10$ & $65-75$ & $0.9-1.0$ & $10-15$ & $10-15$ \\
& 2 & Fill & $110-120$ & $11-12$ & $75-90$ & $0.9-1.0$ & - & $10-15$ \\
& 3 & Cap & $120-130$ & $11-12$ & $65-75$ & $1.0-1.3$ & - & $10-15$ \\
\hline
\end{tabular}


being dissolved and contributes to relieving the specimen's heat energy during welding.

As shown in Figure 2, the research variable was commenced by the varying sequence of backing gas. First, the R-C joint (root pass - capping) entirely served backing gas. Furthermore, the R-F joint (root pass-fill pass) defined backing gas limited from root pass until fill pass. Lastly, the R joint was only applying backing gas at the root pass. The welding parameter shows in Table 2.

All welds were inspected by non-destructive visual examination by following the criteria of ASME section IX QW-144 and QW-194. The visual inspection equipment was a welding gauge type Cambridge and digital vinier calliper to measure the dimension of weldment profile. Visual was only using a naked eye with a flashlight with minimum 1000 lux light intensity. According to the interpretation and evaluation of visual testing, there was no discontinuity exceeding the applicable code. All specimens were cut and prepared into the cross-section of the welds. Hereinafter, the cross-section degreased in chlorinated solvents abrades with $\mathrm{SiC}$ paper 180 grits to removed burrs. After that, the cross-section of welds was ground to 240,320, 500, 800, 1000, 1500, 2000, and 5000 grit by $\mathrm{SiC}$ paper usage. Once grinding was completed, specimens were polished using 0.05 $\mu \mathrm{m}$ sol-gel alumina suspension according to the standard metallographic technique for

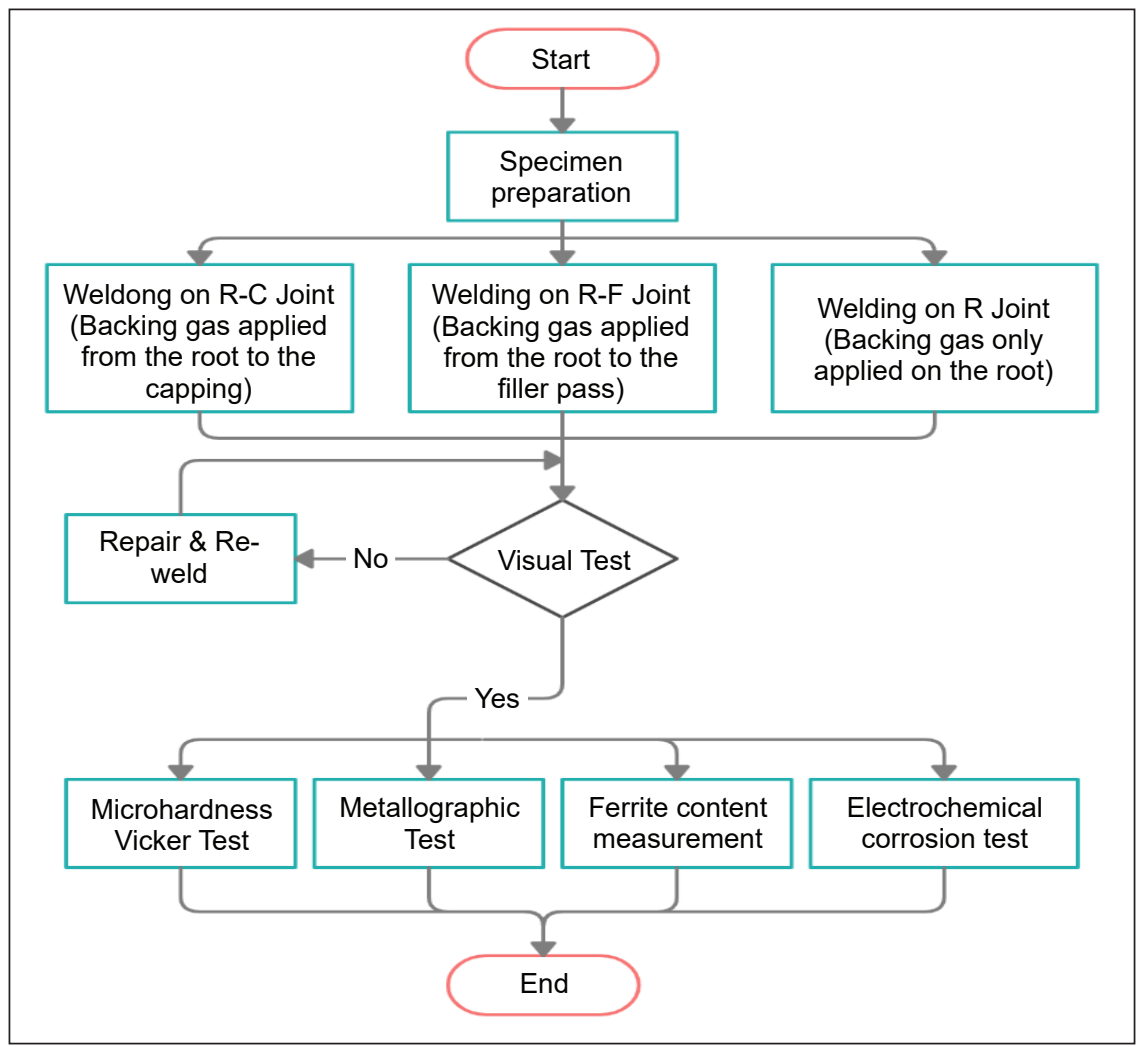

Figure 2. Research flowchart 
etched conditions. The electrolytic etching was performed by creating a solution of $100 \mathrm{ml}$ $\mathrm{H}_{2} \mathrm{O}$, added 10-gram $\mathrm{C}_{2} \mathrm{H}_{2} \mathrm{O}_{4}$ (Oxalic Acid). Hereinafter, the cross-section of weld joints was electrised 12 Voltage 3 Ampere using the direct current power supply for detecting detrimental intermetallic phases.

The metallographic examination of crystal structure was executed in the light microscope with 200x magnification. The ferrite content measurement was performed by ferrite scope, which took a sample from the capping layer, filler pass, and root pass of the varying weld joints. The Hardness Vickers (HV) testing with a load of $5 \mathrm{~kg} f$ was examined on the cross-section of the weldment, which took 18 of HV's indention per the varying joints. The HV's indention was taken from Heat Affected Zone (HAZ), Base Metal (BM), and Weld Metal (WM). The corrosion rates of the research experiment were determined in the electrochemical measurement according to ASTM G102, which was performed by three cell electro system at the scanning rate of $1 \mathrm{mV} / \mathrm{s}$ with a mixed solution of 5 Liter water and 3.5\% HCL. Autolab PGSTAT302N was the instrument being used to conduct linear polarisation. The electrodes include work electrode, which is made from all variants of weldment; reference electrode made from Silver/ Silver Chloride ( $\mathrm{Ag} / \mathrm{AgCl})$; and counter electrode from Platinum (Pt). According to the ASTM G102 standard (ASTM G102-89(2015)e1, 2015), this research use Faraday's law to calculate the corrosion rate the form Penetration Rate (CR) in units of ( $\mathrm{mm} /$ year), as expressed in Equation 1:

$$
C R=K_{1}\left(\frac{i_{\text {corr }}}{\rho}\right) E W
$$

Where,

CR define Corrosion Rate in ( $\mathrm{mm} /$ year)

$I_{\text {corr }}$ is density of the corrosion current $\left(\mu \mathrm{A} / \mathrm{cm}^{2}\right)$

$\mathrm{K}_{1}=3.27 \times 10^{-3},(\mathrm{~mm} \mathrm{~g} / \mu \mathrm{A} \mathrm{cm}$ year $)$

$p$ is density of the material in $\left(\mathrm{g} / \mathrm{cm}^{3}\right)$

Furthermore, EW means equivalent weight or the amount of metal mass that will be oxidised when getting an electric charge of one Faraday. Therefore, EW can be expressed in Equation 2:

$$
E W=\frac{1}{Q}
$$

The $\mathrm{Q}$ value for a material consisting of several elements is calculated based on the formula as shown in Equation 3:

$$
Q=\sum \frac{n_{i} f_{i}}{W_{i}}
$$

Where, 
$\mathrm{n}$ is the number of valence electrons of the constituent elements of the metal alloy

$\mathrm{f}$ is the mass fraction of the constituent elements of the metal alloy

$\mathrm{W}$ is the atomic weight of the alloying elements

The metal constituents used to calculate $\mathrm{Q}$ are elements with a mass fraction greater than $1 \%$. Therefore, in accordance with the test results of the DSS type 2205 specimen's material composition, we only use the element FE to calculate Q.

The calculation of corrosion rate was conducted automatically by NOVA software. The parameters were density of Fe at $7.8 \mathrm{gram} / \mathrm{cm}^{3}$ and EW valued at $55.84 \mathrm{gram} / \mathrm{mol}$. The execution of the electrochemical test began with the dimensional measurement of the sample using a vernier calliper and calculated the area, and then connected the instrument to the electrodes. Hereinafter, created the mixing solution and soaked the electrodes in this mixing solution for 55 minutes. Next, measure the potential value using the AVO meter toward the reference electrode. The value indicates the free corrosion potential $\left(\mathrm{E}_{\text {corr }}\right)$. Then, they turned on the instrument, adjusted the voltage until the potential metal value was shown $50 \mathrm{mV}$ below $\mathrm{E}_{\text {corr. }}$ Finally, NOVA software will automatedly calculate the corrosion rate. Repeat all the steps for all variants of a specimen.

\section{RESULT AND DISCUSSION}

\section{Effect of Reduction of Backing Gas Sequence on Microstructure}

The etching process is applied to the cross-section of weldments that will emerge from the weld zone. Hereinafter, examination conducts in the light microscope with 200x magnification. The microstructure of the 2205 base metal observed that morphology consists of two phases: the ferrite in dark grey colour and the austenite in white grey, as presented in Figure 3.

According to the Fe-Cr-Ni ternary alloy phase diagrams, the 2205 DSS comprises d-ferrite when cooled from the solidification point to $1200^{\circ} \mathrm{C}$. Following a high cooling rate from 1200 to $800^{\circ} \mathrm{C}$, austenite (g-phase) is precipitated from the ferrite's grain boundary (d-phase). The nucleated austenite evolves into flakes and grows as Widmanstatten plates into the d-ferrite grains (Kordatos et al., 2001; Wu et al., 2017). The morphology appearance of 2205 base metal is a clear boundary in the elongated and white-grey austenite distributed into the ferrite matrix. The phase fraction is composed in equal amounts and distributed uniformly along the rolling direction. All of the varying weld joints indicated no influence on the excessive evolution of austenite to ferrite fraction in the base metal during the welding process caused by the reduction of backing gas.

The microstructure of the fusion zone presents the coarser microstructure and columnar grains, as shown in Figure 4. The DSS weld's epitaxial and competitive ferrite grain growth promotes a coarse and columnar ferrite grain structure (Lippold \& Kotecki, 2005). The ferrite phase in Figures 4 (a) and 4(b) is presented in columnar grains. The austenite phase 
nucleated at the ferrite grain boundaries and formed a continuous distributed network. A fraction of this newly transformed ferrite is retained upon rapid cooling triggered by full backing gas usage. Thus, the ferrite-to-austenite transformation is incomplete-a smaller austenite fraction results in the R-C weld pass deposit area. Since a portion of the original austenite fraction has transformed and retained as ferrite fraction, the austenite fraction in the R-C weld pass was decreased, as shown in Figures 4(a) and 4(b). However, the high

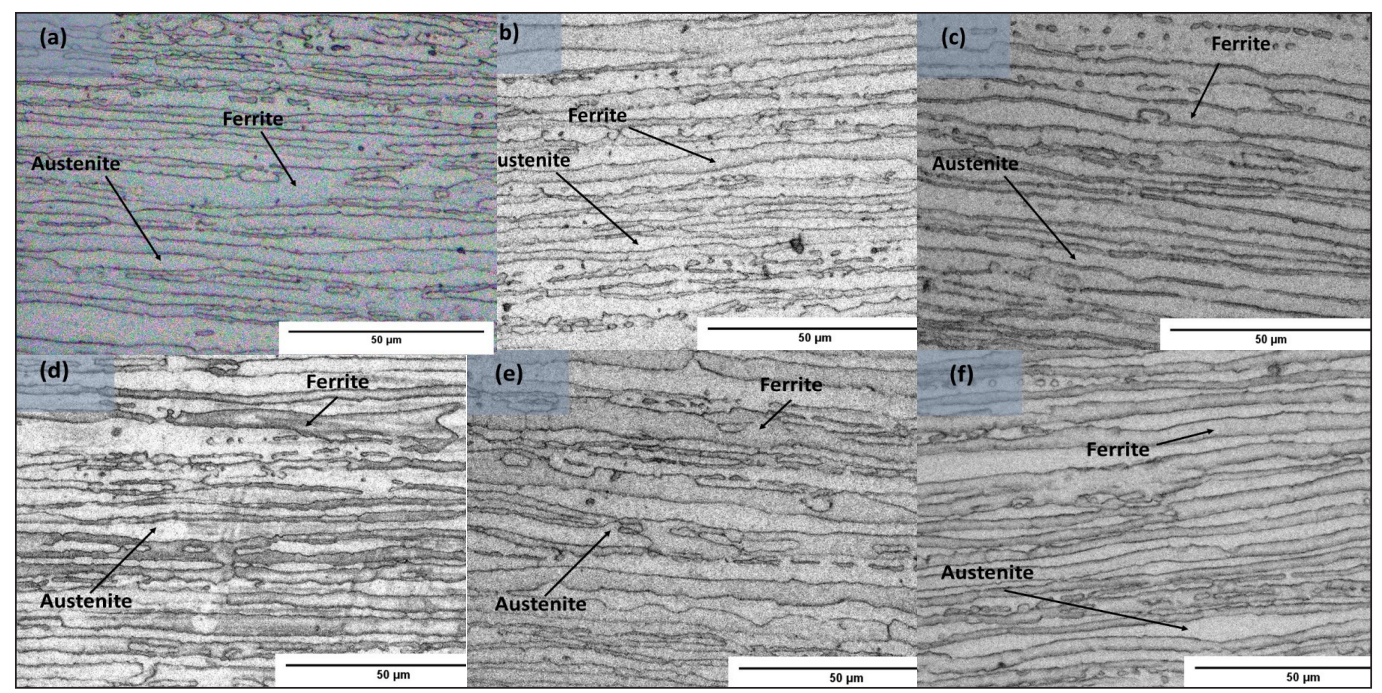

Figure 3. Base metal microstructure of weld joints \#1 and \#2: (a) (b) represent an R-C joint, (c) (d) define an R-F joint, and (e) (f) is an R joint. The ferrite phase is in dark-grey, and austenite is in white-grey

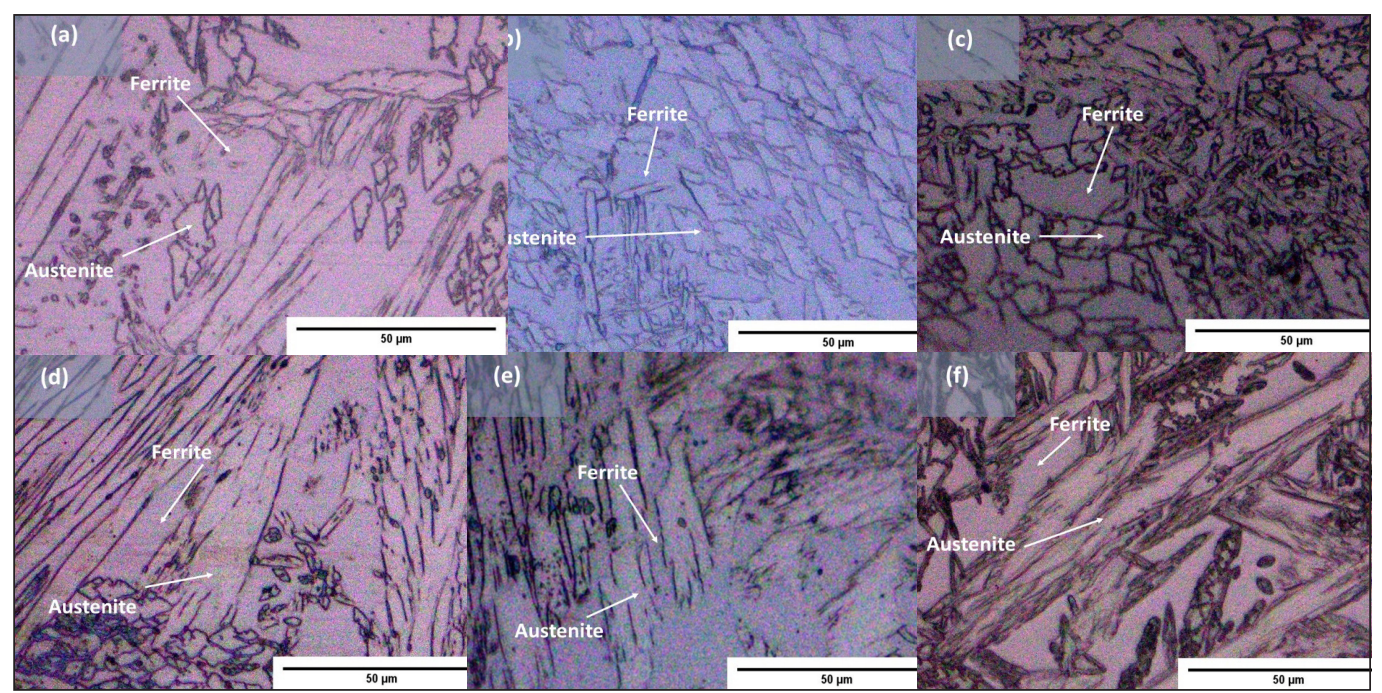

Figure 4. Weld microstructure of weld joints \#1 and \#2: (a) (b) represent an R-C joint, (c) (d) define an R-F joint, and (e) (f) is an R joint. The ferrite phase is in dark grey, and austenite is in white grey 
austenite microstructure obtained in Figures 4(c), 4(d), 4(e), and 4(f) while backing gas sequence being reduced. Due to the effect on the weld thermal cycle, the weld heat input has been shown to have a significant influence on the microstructure. In contrast, high heat input (low cooling rate) prevents excessive ferrite grain growth in these weld regions. The multipass welding simulations in this experiment showed that solid-state reheating of aswelded microstructures would increase austenite fraction in the weld metal. Thus, using reduction of the backing gas sequence shows the lower cooling rate, which is resulted in an increasing austenite fraction in the HAZ because there was more time for nitrogen diffusion during the solid-state ferrite-to-austenite phase transformations (Gozarganji et al., 2021; Kordatos et al., 2001; Varbai et al., 2019).

\section{Effect of Controlling Thermal Cycle on Austenite/ Ferrite Ratio}

The emergence of the weld zone due to the etching process will aid to determine the ferrite content measurement spot. The ferrite scope measures six spots per weld joint variation, which spread on the capping, the side weld, and the root. As indicated in the previous microstructure sub-section, the $\mathrm{A} / \mathrm{F}$ ratio balance in fusion zone microstructures is influenced by the local weld thermal cycle and compositional effects. The weld thermal cycle depends on the cooling rate in the specific transformation temperature range. On the other hand, a good compositional effect relays on the base alloy composition, filler metal composition, and shielding gas composition. Interestingly, Zhang et al. (2016) found that using filler metal ER2209 combined GTAW in the DSS weldment can be an austenite stabiliser, which promotes face-centred cubic structure, resulting in good toughness and pitting resistance. Figure 5 shows the value of ferrite content measurement using the ferrite scope.

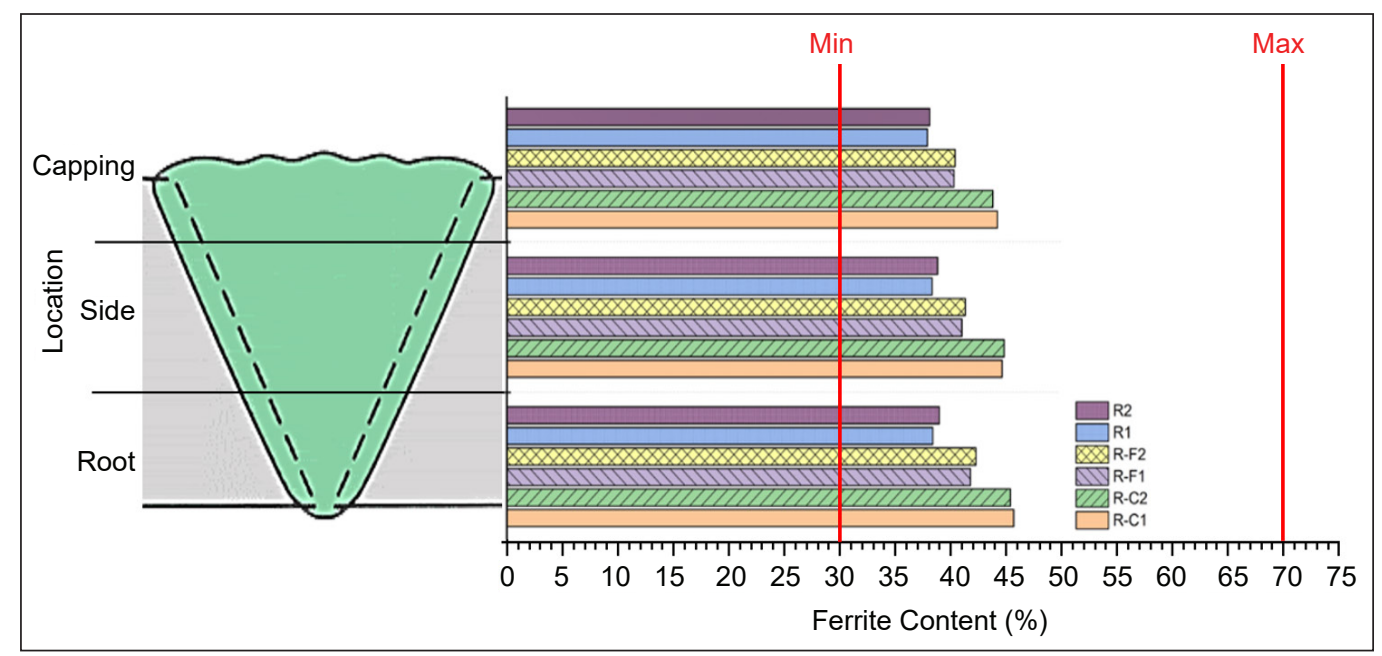

Figure 5. Ferrite content measured in all varying of the weld joint \#1 and \#2 
The $\mathrm{R}-\mathrm{C}$ weld joint obtains the highest ferrite content than other varying weld joints because a higher cooling rate influenced by utilising backing gas will be decreasing the austenite fraction. In Figure 5 can be understood that reducing of backing gas sequence is significantly affected by ferrite fraction. According to ISO 15156-3, the ferrite content in the fusion welded joint should be within the range of 30\% to $70 \%$ (ISO 15156-3, 2015). Therefore, ferrite content on all varying weld joints is approximately $38 \%$ to $45 \%$ which means within in range acceptable standard.

\section{Effect of Cooling Rate on Hardness}

HV's indention has 18 spots per the varying joint with a load of $5 \mathrm{kgf}$, which spreads the $B M$, the $H A Z$, and the $W M$. Figure 6 presents the microhardness Vickers of weld joint \#1 and weld joint \#2. Figures 6(a) and 6(b) shows that the microhardness value on the weld metal (WM) of the R-C weld joints is the highest value than of the R-F weld joint and the R weld joint. Varbai et al. (2019) found that the high cooling rate increases the ferrite fraction, which provides a high microhardness value. Due to the utilising of backing gas,

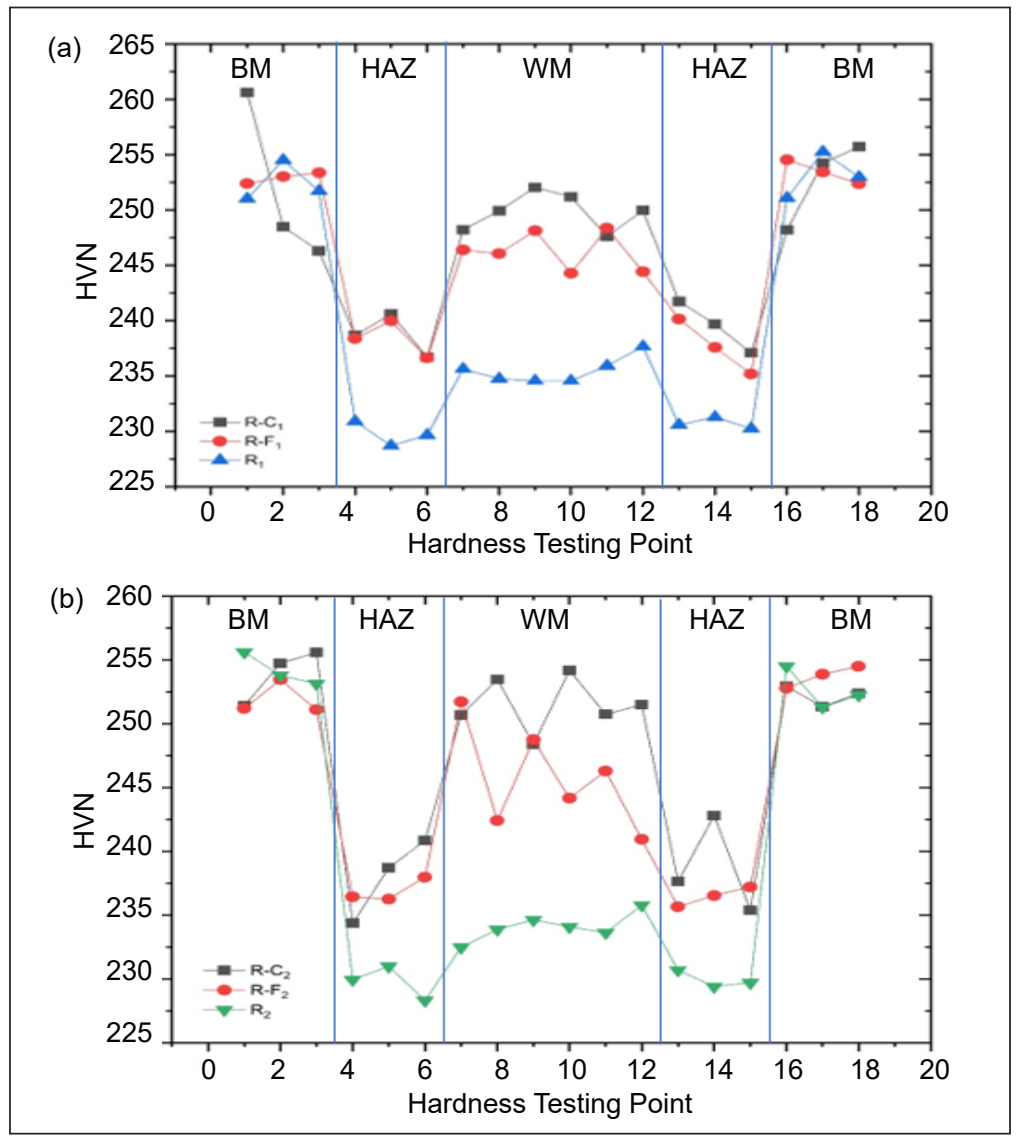

Figure 6. Microhardness Vickers of (a) weld joint \#1; (b) weld joint \#2 
a high cooling rate was obtained, whereas the R-F weld joint and the R weld joint are slightly lower hardness values upon backing gas sequence being reduced. However, the mechanical property of welded 2205 DSS does not vary considerably for normal heat input ( 0.3 to $2.0 \mathrm{~kJ} / \mathrm{mm}$ ) or a weld metal of ferrite level between $23 \%$ and $53 \%$ (Giridharan \& Murugan, 2009; Hertzman, 2001; Verma \& Taiwade, 2017). Accordingly, heat input being applied is around 0.9 to $1.3 \mathrm{~kJ} / \mathrm{mm}$ in Table 2, and ferrite level acquired about $38 \%$ to $45 \%$. As shown in Figure 6, there is no significant effect on microhardness by reducing the backing gas sequence.

\section{Electrochemical Corrosion Resistance}

Based on the result of linear polarisation using the Autolab PGSTAT302N and calculated by NOVA software in electrochemical using three cell electrodes, obtains corrosion rate of welded joint with all varying backing gas on the DSS weldment is presented in Table 3.

The highest corrosion resistance value was found in the $\mathrm{R}-\mathrm{C}_{2}$ specimen at $0.012 \mathrm{~mm} /$ year, while the lowest was found in the $\mathrm{R}_{1}$ specimen at $0.062 \mathrm{~mm} /$ year. In Figure 5, the $\mathrm{R}-\mathrm{C}$ weld joint has about $45 \%$ of ferrite level, which indicates the highest value over another varying weld joint. The huge amount of ferrite fraction in weldment contributes to better corrosion resistance toward the DSS weldment. The high cooling rate influenced by the backing gas utilisation lets ferrite fraction grow widely, as shown in the R-C weld joint. Consequently, reducing of backing gas sequence gives a slightly decreasing ferrite level in weldment, as shown in Figure 5. In many industrial applications, a ferrite content of 35\% to $65 \%$ is recommended for optimum corrosion resistance (Lippold \& Kotecki, 2005; ISO 15156-3, 2015; Varol et al., 1992; Verma \& Taiwade, 2017). According to ASTM A 923, the maximum acceptable corrosion rate is 10 mdd (ASTM A923-14, 2014). The equivalency of $1 \mathrm{~mm} /$ year is $250 \mathrm{mdd}$ which means $10 \mathrm{mdd}$ equal to $0.040 \mathrm{~mm} /$ year (Charles, 2013). The average corrosion rate of the $\mathrm{R}$ weld joint does not pass the maximum acceptable in ASTM A 923. Despite the corrosion rate of the $\mathrm{R}$ weld joint is slightly exceeding the maximum value, its ferrite content is about $38 \%$ within the recommended range for optimum corrosion

Table 3

Experimental results of electrochemistry

\begin{tabular}{ccccccc}
\hline No & $\begin{array}{c}\text { Specimen } \\
\text { ID }\end{array}$ & $E_{\text {corr }}(\mathrm{mV})$ & $i_{\text {corr }}\left(\mu \mathrm{A} / \mathrm{cm}^{2}\right)$ & $\begin{array}{c}\text { Polarisation } \\
\text { resistant }(\mathrm{k} \Omega)\end{array}$ & $\begin{array}{c}\text { Corrosion Rate } \\
(\mathrm{mm} / \text { years })\end{array}$ & $\begin{array}{c}\text { Average } \\
\text { Corrosion Rate } \\
(\mathrm{mm} / \text { years })\end{array}$ \\
\hline \multirow{2}{*}{1} & $\mathrm{R}-\mathrm{C}_{1}$ & -40.42 & 3.07 & 9.02 & 0.017 & 0.014 \\
& $\mathrm{R}-\mathrm{C}_{2}$ & 29.24 & 113.03 & 99.56 & 0.012 & 0.040 \\
2 & $\mathrm{R}-\mathrm{F}_{1}$ & -2.23 & 497.09 & 7.29 & 0.046 & 0.034 \\
& $\mathrm{R}-\mathrm{F}_{2}$ & 94.13 & 747.07 & 36.77 & 0.062 & 0.054 \\
\hline
\end{tabular}


resistance. The $\mathrm{R}$ weld joint can be applied as long as not in an aggressive environment, but further corrosion protection is needed. Additionally, Conradi et al. (2012) stated that the application of DSS 2205 in many aggressive environments, such as a chloride-ion environment, required to spray a thin polymer coating synthesized from 30-nm and 600$\mathrm{nm}$ silica particles dispersed in polyvinyl chloride (PVC), which is improving corrosion resistance. Reducing the backing gas sequence method can substitute full backing gas consumption in the R-F weld joint because it has approximately $40 \%$ ferrite level and corrosion rate acquired $0.040 \mathrm{~mm} /$ year.

\section{CONCLUSION}

In this paper, the reduction of the backing gas sequence in the 2205 DSS weldment was studied. The influence of the thermal cycle due to the reduction of the backing gas sequence will affect the microstructure, microhardness, and corrosion resistance. The effect of various reductions of the backing gas sequence has been investigated for below 10-mm thick. Combining the GTAW process and ER2209 filler metal provides the soundness welds as represented in the microstructure. Even using the $\mathrm{R}$ weld joint was not affected the hardness value because the heat input was applied around 0.9 to $1.3 \mathrm{~kJ} / \mathrm{mm}$. By controlling heat input will lead to the balance A/F ratio. Ferrite content acquired about $38 \%$ to $45 \%$, which is accepted within the various applicable industrial standard. The $\mathrm{R}$ weld joint showed slightly improper corrosion resistance and did not pass ASTM A932 acceptance criteria. However, the R-F weld joint's use improved the sufficient corrosion resistance at $0.04 \mathrm{~mm} /$ year, which reached the requirement of ASTM A932. Thus, reducing the backing sequence affects backing gas consumption and costs a desirable quality corrosion resistance with a lower deviation standard.

\section{ACKNOWLEDGEMENT}

The authors would like to express their special thanks to Lembaga Pengelola Dana Pendidikan (LPDP) Republik Indonesia, who sponsored this work.

\section{REFERENCES}

ASTM A923-14. (2014). Standard test methods for detecting detrimental intermetallic phase in duplex austenitic/ferritic stainless steels. ASTM Internasional.

ASTM G102-89(2015)e1. (2015). Standard practice for calculation of corrosion rates and related information from electrochemical measurements. ASTM Internasional.

Badji, R., Bouabdallah, M., Bacroix, B., Kahloun, C., Belkessa, B., \& Maza, H. (2008). Phase transformation and mechanical behavior in annealed 2205 duplex stainless steel welds. Materials Characterization, 59(4), 447-453. https://doi.org/10.1016/j.matchar.2007.03.004 
Baghdadchi, A., Hosseini, V. A., Hurtig, K., \& Karlsson, L. (2020). Promoting austenite formation in laser welding of duplex stainless steel - Impact of shielding gas and laser reheating. Welding in the World, 65 , 499-511. https://doi.org/10.1007/s40194-020-01026-7

Betini, E. G., Gomes, M. P., Mucsi, C. S., Orlando, M. T. D. A., Luz, T. D. S., Avettand-Fènoël, M. N., \& Rossi, J. L. J. M. R. (2019). Effect of nitrogen addition to shielding gas on cooling rates and in the microstructure of thin sheets of duplex stainless steel welded by pulsed gas tungsten arc welding process. Materials Research, 22(Suppl 1), Article e20190247. https://doi.org/10.1590/1980-5373-mr-2019-0247

Bhattacharya, A., \& Singh, P. M. (2007). Stress corrosion cracking of welded 2205 duplex stainless steel in sulfide-containing caustic solution. Journal of Failure Analysis and Prevention, 7(5), 371-377. https:// doi.org/10.1007/s11668-007-9069-6

Chan, K. W., \& Tjong, S. C. J. M. (2014). Effect of secondary phase precipitation on the corrosion behavior of duplex stainless steels. Materials, 7(7), 5268-5304. https://doi.org/10.3390/ma7075268

Charles, J. (2013). Corrosion resistance properties. In I. Alvarez-Armas \& S. Degallaix-Moreuil (Eds.), Duplex Stainless Steels (pp. 47-114). John Wiley \& Sons, Inc. https://doi.org/10.1002/9781118557990.ch2

Chen, T. H., \& Yang, J. R. (2002). Microstructural characterization of simulated heat affected zone in a nitrogencontaining 2205 duplex stainless steel. Materials Science and Engineering: A, 338(1-2), 166-181. https:// doi.org/10.1016/S0921-5093(02)00065-5

Chern, T. S., Tseng, K. H., \& Tsai, H. L. (2011). Study of the characteristics of duplex stainless steel activated tungsten inert gas welds. Materials \& Design, 32(1), 255-263. https://doi.org/10.1016/j.matdes.2010.05.056

Conradi, M., Kocijan, A., Zorko, M., \& Jerman, I. J. P. i. O. C. (2012). Effect of silica/PVC composite coatings on steel-substrate corrosion protection. Progress in Organic Coatings, 75(4), 392-397. https:// doi.org/10.1016/j.porgcoat.2012.07.008

Geng, S., Sun, J., Guo, L., \& Wang, H. (2015). Evolution of microstructure and corrosion behavior in 2205 duplex stainless steel GTA-welding joint. Journal of Manufacturing Processes, 19, 32-37. https://doi. org/10.1016/j.jmapro.2015.03.009

Giridharan, P. K., \& Murugan, N. (2009). Optimization of pulsed GTA welding process parameters for the welding of AISI 304L stainless steel sheets. The International Journal of Advanced Manufacturing Technology, 40, 478-489. https://doi.org/10.1007/s00170-008-1373-0

Gozarganji, E. H., Farnia, A., \& Ebrahimnia, M. (2021). Effect of shielding gas composition on geometry and austenite formation in low power pulsed Nd: YAG laser welded 2205 duplex stainless steel. Archives of Metallurgy and Materials, 66, 187-195. https://doi.org/10.24425/amm.2021.134775

Hertzman, S. (2001). The influence of nitrogen on microstructure and properties of highly alloyed stainless steel welds. ISIJ International, 41(6), 580-589. https://doi.org/10.2355/isijinternational.41.580

ISO 15156-3. (2015). Petroleum and natural gas industries - Materials for use in H2S-containing environments in oil and gas production - Part 3: Cracking-resistant CRAs (corrosion resistant alloys) and other alloys. ISO.

Karlsson, L., Pak, S., \& Ryen, L. (1995). Precipitation of intermetallic phases in $22 \%$ Cr duplex stainless weld metals. Welding Journal, 74(1), 28-38. 
Kordatos, J., Fourlaris, G., \& Papadimitriou, G. (2001). The effect of cooling rate on the mechanical and corrosion properties of SAF 2205 (UNS 31803) duplex stainless steel welds. Scripta Materialia, 44(3), 401-408. https://doi.org/10.1016/S1359-6462(00)00613-8

Liou, H. Y., Hsieh, R. I., \& Tsai, W. T. (2002). Microstructure and pitting corrosion in simulated heat-affected zones of duplex stainless steels. Materials Chemistry and Physics, 74(1), 33-42. https://doi.org/10.1016/ S0254-0584(01)00409-6

Lippold, J. C., Baeslack III, W. A., \& Varol, I. (1988). Heat-affected zone liquation cracking in austenitic and duplex stainless steels. Welding Journal, 71(1), 1s-14s.

Lippold, J. C., \& Kotecki, D. J. (2005). Welding metallurgy and weldability of stainless steels. Wiley-VCH.

Liu, Z., Fan, C. L., Ming, Z., Chen, C., Liu, A., Yang, C. L., Lin, S. B., \& Wang, L. P. (2020). Gas metal arc welding of high nitrogen stainless steel with Ar-N2-O2 ternary shielding gas. Defence Technology, 17(3), 923-931. https://doi.org/10.1016/j.dt.2020.05.021

Matsunaga, H., Sato, Y. S., Kokawa, H., \& Kuwana, T. (2013). Effect of nitrogen on corrosion of duplex stainless steel weld metal. Science and Technology of Welding and Joining, 3(5), 225-232. https://doi. org/10.1179/stw.1998.3.5.225

Muthupandi, V., Srinivasan, P. B., Shankar, V., Seshadri, S. K., \& Sundaresan, S. (2005). Effect of nickel and nitrogen addition on the microstructure and mechanical properties of power beam processed duplex stainless steel (UNS 31803) weld metals. Materials Letters, 59(18), 2305-2309. https://doi.org/10.1016/j. matlet.2005.03.010

Nana, S., \& Cortie, M. B. (1993). Microstructure and corrosion resistance of experimental low-nickel duplex stainless steels. Journal of the Southern African Institute of Mining and Metallurgy, 93(11), 307-315.

Ramirez, A. J., Lippold, J. C., \& Brandi, S. D. (2003). The relationship between chromium nitride and secondary austenite precipitation in duplex stainless steels. Metallurgical and Materials Transactions A, 34(8), 1575-1597. https://doi.org/10.1007/s11661-003-0304-9

Ramkumar, K. D., Mishra, D., Raj, B. G., Vignesh, M. K., Thiruvengatam, G., Sudharshan, S. P., Arivazhagan, N., Sivashanmugam, N., \& Rabel, A. M. (2015). Effect of optimal weld parameters in the microstructure and mechanical properties of autogeneous gas tungsten arc weldments of super-duplex stainless steel UNS S32750. Materials \& Design (1980-2015), 66, 356-365. https://doi.org/10.1016/j.matdes.2014.10.084

Sales, A. M., Westin, E. M., \& Colegrove, P. (2016). Effect of nitrogen in backing gas on duplex root weld properties of heavy-walled pipe. Welding in the World, 60(5), 877-882. https://doi.org/10.1007/s40194016-0347-3

Varbai, B., Adonyi, Y., Baumer, R., Pickle, T., Dobranszky, J., \& Majlinger, K. (2019). Weldability of duplex stainless steels - Thermal cycle and nitrogen effects. Welding Journal, 98(3), 78-87. https://doi. org/10.29391/2019.98.006

Varol, I., Lippold, J. C., \& Baeslack, W. A. (1992). Welding of duplex stainless steels. In D. L. Olson \& T. H. North (Eds.), Key Engineering Materials (Vol. 69, pp. 217-252). Trans Tech Publications Ltd. https://doi. org/10.4028/www.scientific.net/KEM.69-70.217 
Verma, J., \& Taiwade, R. V. (2017). Effect of welding processes and conditions on the microstructure, mechanical properties and corrosion resistance of duplex stainless steel weldments - A review. Journal of Manufacturing Processes, 25, 134-152. https://doi.org/10.1016/j.jmapro.2016.11.003

Wang, S., Ma, Q., \& Li, Y. (2011). Characterization of microstructure, mechanical properties and corrosion resistance of dissimilar welded joint between 2205 duplex stainless steel and 16MnR. Materials \& Design, 32(2), 831-837. https://doi.org/10.1016/j.matdes.2010.07.012

Wu, M., Liu, F., Pu, J., Anderson, N. E., Li, L., \& Liu, D. (2017). The microstructure and pitting resistance of weld joints of 2205 duplex stainless steel. Journal of Materials Engineering and Performance, 26(11), 5341-5347. https://doi.org/10.1007/s11665-017-2976-0

Zhang, Z., Jing, H., Xu, L., Han, Y., \& Zhao, L. (2016). Investigation on microstructure evolution and properties of duplex stainless steel joint multi-pass welded by using different methods. Materials \& Design, 109, 670-685. https://doi.org/10.1016/j.matdes.2016.07.110 
